\title{
TRAINING WRITING NONFICIAL STORIES IN STUDENTS OF THE PGSD STUDY PROGRAM WIDYA DHARMA KLATEN UNIVERSITY
}

\author{
Bayu Purbha Sakti \\ Universitas Widya Dharma Klaten \\ bayups@unwidha.ac.id
}

\begin{abstract}
ABSTRAK
Mahasiswa-mahasiswi Program Studi Pendidikan Guru Sekolah Dasar (PGSD) Universitas Widya Dharma diharapkan memiliki wawasan dan pengetahuan dalam penulisan cerita nonfiksi atau berita nyata. Tujuan dari program kegiatan pengabdian ini adalah untuk melatih para mahasiswa calon guru sekolah dasar untuk dapat menulis cerita nonfiksi atau berita nyata. Metode yang digunakan dalam kegiatan pengabdian ini adalah pemberian pelatihan dengan metode ceramah, diskusi, dan tanya jawab. Hasil yang didapatkan pada pelatihan menulis cerita nonfiksi adalah minat peserta dan urgensi berita. Para peserta pelatihan menulis cerita nonfiksi memiliki minat menjadi tertarik untuk menulis cerita nonfiksi atau berita nyata karena hal tersebut akan menjadi informasi yang berguna di masyarakat. Urgensi berita nyata harus disampaikan karena berita yang nyata akan memberikan kebenaran yang harus dipahami oleh semua pihak tidak terkecuali anak sekolah dasar.

Kata Kunci: Cerita Nonfiksi, Berita Nyata, Anak Sekolah Dasar
\end{abstract}

\section{ABSTRACT}

Widya Dharma University Primary School Teacher Education (PGSD) Study Program students are expected to have insight and knowledge in writing nonfiction stories or real news. The purpose of this service activity program is to train prospective elementary school teacher students to be able to write nonfiction stories or real news. The method used in this service is the provision of training with lecture, discussion, and question and answer methods. The results obtained in the training of writing nonfiction stories are the participants' interest and the urgency of the news. The trainees writing nonfiction stories have an interest in being interested in writing nonfiction stories or real news because it will be useful information in the community. The urgency of real news must be delivered because real news will provide truth that must be understood by all parties including elementary school children.

Keywords: Nonfiction Stories, Real News, Elementary School Children

\section{PENDAHULUAN}

Rektor Universitas Al Azhar Indonesia (UAI) menambahkan jika para profesor mengalami kendala menulis dalam bahasa Inggris yang mudah dibaca (Aini, 2018). Hal itu disebabkan karena waktu profesor habis digunakan untuk mengajar mahasiswa sarjana. Jika dosen sudah banyak mengajar maka dosen yang bersangkutan akan kesulitan 
menemukan waktu untuk menulis cerita yang bersumber dari bahasa inggris. Resiko yang diterima dosen tersebut akan menular kepada mahasiswa yang diajarinya. Jika ada cerita nonfiksi yang bersumber dari buku bahasa inggris dan mahasiswa tidak bisa menulis cerita yang bersumber dari buku tersebut maka akan menjadi masalah. Sebaliknya jika mahasiswa tidak bisa menuliskan cerita nonfiksi dalam bahasa inggris maka hal itu juga akan menjadi tanda tanya tentang kemampuan berbahasa inggris yang dimiliki mahasiswa.

Tim cyber Direskrimsus Kepolisian Daerah (Polda) Nusa Tenggara Timur menciduk seorang mahasiswa yang diketahui menulis dan menyebarkan berita ancaman bom pada salah satu pusat perbelanjaan di Kota Kupang lewat jejaring media sosial Facebook (Lewokeda, 2018). Hal tersebut tentu saja menjadi keresahan yang dirasakan masyarakat. Mahasiswa seharusnya memberikan contoh yang baik tentang menulis cerita nonfiksi atau berita nyata sebelum mereka akan menyebarkannya. Oleh karena itu kegiatan perkuliahan yang dibutuhkan mahasiswa selain pendidikan karakter supaya mahasiswa tidak suka mengancam adalah penulisan cerita nonfiksi atau berita nyata yang benar. Hal itu harus dilakukan supaya mahasiswa dapat memberikan informasi yang tidak menimbulkan ancaman dalam penyebarannya di media sosial.

Buku juga merupakan salah satu hasil karya menulis cerita nonfiksi. Kesulitan dosen menulis buku adalah masalah referensi padahal saat ini referensi begitu mudah didapat (Sarnapi, 2018). Kesulitan tersebut disebabkan salah satunya kemampuan dosen yang gagap dalam menghadapi kedatangan era revolusi industri 4.0 dimana kegiatan pembelajaran dituntut secara digital. Apabila dosen saja masih mengalami kesulitan dalam menuliskan beberapa bagian yang berguna dalam penulisan cerita nonfiksi atau berita nyata maka mahasiswanya tentunya akan diajari dengan kesalahan yang didapat tersebut. cerita nonfiksi atau berita nyata dapat dituliskan dalam dunia maya atau digital pada era revolusi industri 4.0. Buku cerita nonfiksi atau berita nyata juga dapat diunggah dan diunduh dengan mudahnya dari dunia maya atau dunia digital atau yang dapat dikenal dengan istilah website.

Menulis cerita nonfiksi juga membutuhkan referensi. Buku nonfiksi yang dicetak tanpa disertai referensi data yang jelas maka bisa disebut dengan kebohongan (Movanita, 2017). Ada dugaan Pidana Undang-undang Informasi dan Transaksi Elektronik (UU ITE) pada buku nonfiksi yang dicetak tidak jelas. Masalah tersebut dapat menjadi kasus di pengadilan. Oleh karena itu para penulis buku nonfiksi harus memahami peraturan dan 
hukum yang berlaku supaya mereka tidak menimbulkan masalah di kemudian hari. Oleh karena itu para mahasiswa yang memiliki minat dan ingin fokus dalam menulis berita atau cerita nonfiksi maka mereka harus memahami hal yang berkaitan dengan peraturan dan hukum.

Mahasiswa-mahasiswi Program Studi (Prodi) Pendidikan Guru Sekolah Dasar (PGSD) Universitas Widya Dharma (Unwidha) Klaten diharapkan memiliki wawasan dan pengetahuan dalam penulisan cerita nonfiksi. Berita yang merupakan bagian dari Cerita nonfiksi juga akan disukai anak Sekolah Dasar (SD) nantinya. Oleh karena itu para calon guru SD sudah sepantasnya pandai dan kreatif dalam menulis dan menyusun cerita nonfiksi. Mahasiswa Program Studi Pendidikan Guru Sekolah Dasar harus menghasilkan karyakarya supaya dipahami anak sekolah dasar (Sakti, 2018b). oleh karena itu, para mahasiswa Prodi PGSD Unwidha diharapkan dapat menulis cerita nonfiksi supaya mereka dapat menjadi pemberi cerita atau berita yang benar-benar nyata dan sesuai realita kehidupan. Para mahasiswa tersebut adalah calon guru dimana mereka akan mengajari anak sekolah dasar yang memerlukan pengetahuan tulisan-tulisan cerita atau berita-berita yang nyata.

Penulis telah mengamati tentang penulisan berita dan cerita yang dilakukan para mahasiswa Prodi PGSD Unwidha Klaten semester lima di tahun 2018. Penulis merasa ada beberapa kesalahan dalam menuliskan berita dan cerita yang bersifat nyata yang telah dilakukan para mahasiswa tersebut. Salah satu kesalahan yang diamati adalah tidak adanya kejelasan tentang penulisan waktu kejadian berita atau cerita. Oleh karena itu, penulis ingin memberikan pelatihan supaya ada sesuatu yang harus dibenahi dan dilengkapi para mahasiswa tersebut untuk menghindari terjadinya berita atau cerita bohong.

Tujuan dari program kegiatan pengabdian ini adalah untuk melatih para mahasiswa calon guru sekolah dasar untuk dapat menulis cerita atau berita nyata. Para mahasiswa tersebut diharapkan dapat mengetahui unsur atau komponen penyusun tulisan cerita atau berita nonfiksi. Kegunaan dari program kegiatan pengabdian ini adalah supaya menjadi program yang dapat ditiru oleh lembaga pendidikan lainnya akan pentingnya penulisan cerita atau berita nonfiksi. Target yang ingin dicapai sebenarnya tidak hanya para mahasiswa Prodi PGSD saja tetapi para mahasiswa dari beberapa prodi di fakultas pendidikan. Luaran yang ingin dicapai adalah hasil tulisan cerita nonfiksi dari kegiatan pengabdian. 


\section{METODE PELAKSANAAN}

Metode yang digunakan dalam kegiatan pengabdian ini adalah pemberian pelatihan dengan beberapa metode yang digunakan. Metode penyampaiannya adalah metode ceramah, diskusi, dan tanya jawab. Pelaksanaan kegiatan pelatihan dilakukan pada hari Senin sampai dengan hari Rabu pada tanggal 19 sampai dengan 21 Maret 2018. Pelaksanaan kegiatan pelatihan berlangsung selama 15 jam. Kegiatan dimulai dari jam 08.00 s.d 13.00 WIB dan ada acara yang diatur secara fleksibel. Kegiatan pelatihan dihadiri mahasiswa Program Studi Pendidikan Guru Sekolah Dasar Universitas Widya Dharma. Alat yang digunakan dalam pelatihan menulis cerita nonfiksi adalah laptop dan proyektor. Bahan yang digunakan dalam pelatihan menulis cerita nonfiksi adalah materi pelatihan, alat tulis, dan buku tulis.

Materi yang diberikan dalam pelatihan berkaitan dengan kemampuan aspek menulis berita dan cerita nonfiksi atau nyata bagi calon guru sekolah dasar. Kegiatan pelatihan ini dilakukan dengan melakukan pemberian pelatihan penulisan berita sebagai cerita nonfiksi. Materi pelatihan sangat penting untuk dipahami dan diterapkan bagi mahasiswa Program Studi Pendidikan Guru Sekolah Dasar Universitas Widya Dharma.

Cara kerja yang dilakukan dari pelatihan menulis cerita nonfiksi adalah dengan menjelaskan materi yang ditampilkan dari proyektor. Pemateri menjelaskan beberapa materi dengan berceramah di depan ruang kelas. Para peserta juga diminta bertanya jawab pada sesi berikutnya meskipun mereka sudah atau belum memahami materi. Para peserta juga diminta berdiskusi pada sesi yang lain untuk lebih menjalin kerjasama dalam satu kelompok yang beranggotakan lebih dari dua peserta.

\section{HASIL DAN PEMBAHASAN}

Hasil yang didapatkan dari kegiatan pengabdian masyarakat dengan pemberian pelatihan penulisan berita sebagai cerita nonfiksi ini membuat para mahasiswa sebagai peserta merasakan urgensi bahwa berita merupakan bagian penting pada perkembangan informasi untuk anak sekolah dasar. Mereka menganggap bahwa berita itu penting karena berita merupakan cerita nyata yang harus disampaikan supaya terjadi kebenaran. Urgensi dari pelatihan tentang berita tersebut dapat dijelaskan sebagai berikut.

1. Minat peserta kegiatan pelatihan

Peserta kegiatan pelatihan ini adalah para mahasiswa Program Studi Pendidikan Guru 
Sekolah Dasar (PGSD) Universitas Widya Dharma Klaten (Unwidha). Mahasiswa yang mengikuti adalah mahasiswa PGSD Unwidha angkatan tahun 2016. Mereka adalah calon guru sekolah dasar. Guru sekolah dasar memiliki fungsi dan keahlian dalam menangani anak usia sekolah dasar (Sakti, 2016a). Program studi pendidikan guru sekolah dasar merupakan program studi (prodi) yang mengarahkan mahasiswa untuk memiliki keahlian di bidang sekolah dasar (Sakti, 2017b). Mereka memiliki minat yang besar untuk mengikuti kegiatan pelatihan ini. Mereka memiliki keinginan untuk berprestasi dalam lomba karya tulis tingkat mahasiswa. Para peserta pelatihan menulis cerita nonfiksi menjadi tertarik untuk menulis cerita atau berita nyata karena hal tersebut akan menjadi informasi yang berguna di masyarakat.

Deputi Bidang Ilmu Pengetahuan Teknik Lembaga Ilmu Pengetahuan Indonesia (LIPI) Laksana Tri Handoko mengatakan pada 2015 pihaknya menerima 2.041 proposal dan 600 usulan karya inovasi remaja atau naik sekitar 30 persen dibanding tahun sebelumnya (Inung, 2019). Dari hasil tersebut dapat diketahui bahwa minat remaja memiliki persentase yang meningkat dalam hal menulis. Mahasiswa merupakan tahapan remaja akhir tentunya harus memiliki minat yang lebih dalam menulis berita atau makalah atau karya tulis lainnya. Para mahasiswa PGSD yang mengikuti pelatihan tersebut diharapkan dapat menambah persentase data pada LIPI.

2. Urgensi berita

Penulis memberikan arahan kepada peserta kegiatan pelatihan bahwa berita memiliki makna yang penting. Urgensi berita merupakan cerita nyata yang harus disampaikan supaya terjadi kebenaran yang harus dipahami oleh semua pihak tidak terkecuali anak sekolah dasar. Keluarga dan masyarakat memiliki peran demi keamanan anak usia sekolah dasar (Sakti, 2016b). Berita harus dikabarkan calon guru sekolah dasar supaya siswa, keluarga, dan masyarakat bisa menghindari berita bohong (hoax) Meningkatkan minat baca harus dimulai dari masa kanak-kanak sampai masa sekolah dasar (Sakti, 2017a). Siswa sekolah dasar yang memiliki kecerdasan linguistik secara baik akan mudah menghafal kata-kata dengan tepat dan mempunyai kosakata yang luas (Sakti, 2018a). Oleh karena itu, berita merupakan hal paling penting yang harus dibaca oleh siswa sekolah dasar.

Perlindungan yang diatur dalam standar ini adalah perlindungan hukum untuk wartawan yang menaati kode etik jurnalistik dalam melaksanakan tugas jurnalistiknya 
memenuhi hak masyarakat memperoleh informasi (Pers, 2008). Wartawan, jurnalistik, penulis berita, dan sebagainya sudah saat harus mendapatkan perlindungan hukum. Hal itu harus dilakukan karena berita yang benar akan memberikan gambaran nyata suatu kejadian supaya dapat ditindak lanjuti untuk diadakan penelitian, perubahan data, dan lain-lain. Para peserta pelatihan juga diingatkan supaya menjaga keaslian berita yang ditulis. Mereka akan menjadi ujung tombak berita informasi kebenaran.

Kelebihan dari kegiatan pengabdian ini adalah materi pelatihan menulis cerita nonfiksi yang digunakan sangat bermanfaat untuk menulis materi cerita nonfiksi bagi anak sekolah dasar. Kekurangan dari kegiatan pengabdian ini adalah sasaran peserta pelatihan menulis cerita nonfiksi yang hanya dihadiri para mahasiswa dan mahasiswi Program Studi Pendidikan Guru Sekolah Dasar Universitas Widya Dharma Klaten.

\section{KESIMPULAN}

Kesimpulan yang didapatkan pada kegiatan pengabdian berkaitan dengan minat peserta dan urgensi berita. Para peserta pelatihan menulis cerita nonfiksi memiliki minat menjadi tertarik untuk menulis cerita atau berita nyata karena hal tersebut akan menjadi informasi yang berguna di masyarakat. Urgensi berita merupakan cerita nyata yang harus disampaikan supaya terjadi kebenaran yang harus dipahami oleh semua pihak tidak terkecuali anak sekolah dasar.

\section{REKOMENDASI}

Penulis merekomendasikan pelatihan menulis cerita nonfiksi ini tidak hanya untuk para mahasiswa Program Studi Pendidikan Guru Sekolah Dasar Universitas Widya Dharma Klaten. Rekomendasi yang ditulis tidak juga untuk para mahasiswa fakultas pendidikan, tetapi untuk semua mahasiswa berbagai program studi yang memiliki minat untuk menulis cerita atau berita nonfiksi atau nyata. Penulis mengucapkan terima kasih kepada beberapa pihak yang membantu diselenggarakannya pelatihan menulis cerita nonfiksi. Ucapan terima kasih diberikan kepada pihak Universitas Widya Dharma Klaten dan para mahasiswa Prodi PGSD. 


\section{DAFTAR PUSTAKA}

Aini, N. (2018). Forum Rektor: Waktu Profesor Habis Mengajar Sarjana | Republika Online. $\quad$ Retrieved January 2019, from https://republika.co.id/berita/pendidikan/eduaction/18/02/23/p4ky05382-forumrektor-waktu-profesor-habis-mengajar-sarjana

Inung. (2019). LIPI Gelar Dua Kompetisi Ilmiah Bagi Anak Muda. Retrieved July 10, 2019, from http://lipi.go.id/lipimedia/single/LIPI-Gelar-Dua-Kompetisi-Ilmiah-BagiAnak-Muda/15213

Lewokeda, A. (2018). Polisi ciduk mahasiswa sebar berita ancaman bom lewat medsos ANTARA News. Retrieved January 31, 2019, from https://www.antaranews.com/berita/690696/polisi-ciduk-mahasiswa-sebar-ancamanbom-lewat-medsos

Movanita, A. (2017). Buku “Jokowi Undercover" Dicetak Sekitar 300 Eksemplar. $\begin{array}{llll}\text { Retrieved } \quad \text { February } & \text { 1, 2019, from }\end{array}$ https://nasional.kompas.com/read/2017/01/06/17245661/buku.jokowi.undercover.dice tak.sekitar.300.eksemplar

Pers, D. (2008). Standar Perlindungan Profesi Wartawan. Retrieved July 10, 2019, from https://www.merdeka.com/company/standar-perlindungan-profesi-wartawan.html

Sakti, B. P. (2016a). Etika Dan Profesi Guru SD Di Tengah Perkembangan Zaman. Proceeding PGSD Universitas Kuningan 2016, 1(1), 99-107. Retrieved from https://proceeding.uniku.ac.id/index.php/pgsd2016/article/view/10

Sakti, B. P. (2016b). Indikator Sekolah Dasar Ramah Anak. Prosiding Seminar Nasional $\begin{array}{llll}P K O & \text { FKIP } & \text { UTP, } & \text { Retrieved }\end{array}$ http://ejournal.utp.ac.id/index.php/PROPKO/article/view/596

Sakti, B. P. (2017a). Indikator Pengembangan Karakter Siswa Sekolah Dasar. Magistra Unwidha Klaten, $30, \quad 1 . \quad$ Retrieved from http://journal.unwidha.ac.id/index.php/MAGISTRA/article/view/1/0

Sakti, B. P. (2017b). Persepsi Mahasiswa Program Studi Pendidikan Guru Sekolah Dasar Universitas Widya Dharma Tentang Etika Mahasiswa. Premiere Educandum : Jurnal $\begin{array}{lllll}\text { Pendidikan Dasar Dan Pembelajaran, } & 7(02), & \end{array}$ https://doi.org/10.25273/pe.v7i2.1732 


\section{Jurnal Berdaya Mandiri}

Vol. 1 No. 1 Tahun 2019

P-ISSN:

E-ISSN:

Sakti, B. P. (2018a). Feasibility Indicators Of Study Books Used Elementary School. SHEs: Conference Series 1, l(Snpd), 103-111. Retrieved from https://jurnal.uns.ac.id/SHES/article/view/23556

Sakti, B. P. (2018b). Training of Scientific Papers Writing On Students of Widya Dharma University. CARADDE: Jurnal Pengabdian Kepada Masyarakat, 1(1), 7-12. https://doi.org/10.31960/caradde.v1i1.3

Sarnapi. (2018). Tak Dianggap Ilmuwan Bila Dosen Tak Menulis Buku | Pikiran Rakyat. Retrieved January 31, 2019, from https://www.pikiranrakyat.com/pendidikan/2018/11/26/tak-dianggap-ilmuwan-bila-dosen-tak-menulisbuku-433681 